\title{
Virtual screening: prediksi potensi 8-shogaol terhadap c-Jun N- Terminal Kinase (JNK)
}

\section{${ }^{1 *}$ Yohanes Bare, ${ }^{2}$ Mansur S, ${ }^{3}$ Sri Sulystyaningsih Natalia Daeng Tiring, ${ }^{4}$ Dewi Ratih Tirto Sari, ${ }^{5}$ Andri Maulidi}

\author{
1, 2,3Universitas Nusa Nipa, Jl. Kesehatan No. 03, Maumere, Indonesia, 86111 \\ 4Universitas Brawijaya, Jl. Veteran, Malang, Jawa Timur, Indonesia 65145 \\ ${ }^{5}$ Universitas Palangka Raya, Jl. Yos Sudarso, Palangka Raya, Kalimantan Tengah, Indonesia 73112 \\ *Corresponding Author e-mail: bareyohanes@gmail.com
}

Received: November 2019; Revised: January 2020; Published: March 2020

\begin{abstract}
Abstrak
JNK adalah gen yang berperan dalam metabolisme DMT2. Dalam pengobatan T2DM digunakan JNK sebagai potensi terapi dengan menggunakan bahan alam. 8-shogaol adalah komponen kimia yang terkandung dalam jahe yang memiliki aktivitas antioksidan. Tujuan dari penelitina ini adalah menginversitagasi dan menganalisis peran 8-shogaol terhadap JNK. Protein JNK (ID: 464Y) diperoleh dari Protein Data Bank dan ligan 8-shogaol (CID:6442560) didapat dari pubchem. Ligan dan protein didocking menggunakan Hex 8.0.0. File dalam bentuk pdb divisualtisasi dan analisis menggunakan Discovery Studio Client 4.1 software. Interaksi ligan-protein menunjukan ikatan hidrogen pada residu asam amino LYS93 dan van der Waals pada 18 residu asam amino dengan energi ikatan-289.68cal/mol. Interkasi ini berpotensi sebagai penghambat kerja JNK dan dapat digunakan dalam terapi DMT2.
\end{abstract}

Kata Kunci: 8-shogaol, Jahe, In Silico, JNK, T2DM

\section{Virtual screening: potential prediction of 8-shogaol againts c-Jun N- Terminal Kinase (JNK)}

\begin{abstract}
JNK is one of gene that has a role in T2DM condition. To curve T2DM use JNK as potential healing using natural compounds. Eight-shogaol which found in ginger has function as a antioxidant.. The aim of the research is to investigate and analyze role 8-shogaol againts JNK. Protein JNK (ID: 464Y) was taken from Protein Data Bank and ligand 8-shogaol (CID:6442560) acquired from pubchem. Ligand and protein model were docked using Hex 8.0.0 software. Visualization and analysis molecular interactions by the Discovery Studio Client 4.1 software. Interaction ligand--protein showed one hydrogen bond in amino acid residue LYS93 and formed van der Waals in eighteen amino acid residues which energy binding $-289.68 \mathrm{cal} / \mathrm{mol}$. This interaction has a potential to inhibit JNK role and lead to therapy T2DM.
\end{abstract}

Keywords: 8-shogaol, Ginger, In Silico, JNK, T2DM

How to Cite: Bare, Y., S, M., Tiring, S., Sari, D., \& Maulidi, A. (2020). Virtual Screening: Prediksi potensi 8-shogaol terhadap c-Jun N-Terminal Kinase (JNK). Jurnal Penelitian dan Pengkajian Ilmu Pendidikan: e-Saintika, 4(1), 1-6. doi:https://doi.org/10.36312/e-saintika.v4i1.157

\section{PENDAHULUAN}

Diabetes melitus tipe 2 (DMT2) adalah penyakit degeneratif dengan karakteristik kondisi gula yang sangat tinggi didalam darah. Data badan Kesehatan Dunia (WHO) melaporkan terjadi peningkatan penderita DMT2 dan Indonesia menempati peringkat 5 di kawasan Asia Pasifik (Bare et al., 2018). Berbagai metode penyembuhan dilakukan dengan 
pengobatan, akan tetapi terdapat kajian nutrigenomik dengan mencari gen-gen yang terkait dengan penyakit DMT2. C-Jun Terminal Kinase (JNK) adalah gen berperan terhadap kondisi diabetes. JNK memiliki fungsi dalam jalur metabolisme diabetes. Penyembuhan diabetes memiliki korelasi dengan kamponen penyembuhan berbagai macam penyakit. Gen JNK menjadi target terapi dalam penyembuhan diabetes mellitus (Cui et al., 2007). Pada penelitian sebelumnya Bare et al, (2018) menemukan beberpa pita protein tidak terkespresi pada kondisi diabetes mellitus tipe 2 . Hal ini menyebabkan terjadinya peningkatan inflamasi. Salah satu terapi yang digunakan dalam pengobatan diabetes mellitus adalah menggunakan bioaktif kimia yang berasal dari alam karena memiliki toksisitas yang rendah (Kesuma et al., 2018).

Rimpang jahe (Zingiber officinale Roscoe) famili Zingiberaceae merupakan salah satu tanaman rimpang yang tersedia di alam. Didalam jahe segar terdapat terdapat beberapa kandungan kimia yaitu 4-, 6-, 8-, 10-, dan 12-gingerol, 6-, 8-, 10 shogaol, flavonoid, phenolik (Ghasemzadeh et al., 2018). Penelitian sebelumnya telah mengungkapkan bahwa shogaol adalah produk dari jahe kering dan menunjukkan aktivitas biologis yang lebih tinggi termasuk aktivitas antikanker dan antioksidan (Bhattarai et al., 2001). Penelitian Tiring et al., (2019) menemukan adanya kandungan dari 6-shogaol sebagai inhibitor JNK dan Penelitian Bare et al, (2019) melaporkan aktivitas inhibitor 6-gingerol terhadap gen JNK. Keterbaruan dalam penelitain ini adalah belum diidentifikasi mengenai manfaat kandunagn 8shogaol dalam jahe memiliki potensi sebagai terapi dalam menurunkan prevelensi kasus DMT2 secara nutrigenomik. Tujuan dari penelitian ini menginvestigasi dan menganalisis potensi 8-shogaol dalam rimpang jahe terhadap gen JNK secara virtual screening.

\section{METODE}

\section{Persiapan Protein dan Ligan}

Database Protein Data Bank (database http://www.rcsb.org/pdb/home/home.do) diperoleh protein model c-Jun Nterminal kinases (JNK) dengan ID: 464Y Ligan 8-shogaol dengan CID:6442560 diperoleh dari database PubChem. Energi yang dimiliki oleh 8-shogaol diminimalisir olehperangkat lunak $P y R x$ virtual screening program Open Babel tool dan selanjutnya 8-shogaol diubah kedalam bentuk pdb. Proses selanjutnya adalah dihilangkan molekul air atau ligan yang berikatan dengan protein JNK menggunakan Discovery Studio Client 4.1 (Bare et al., 2019).

\section{Interaksi Molekuler}

Model protein JNK dan ligan 8-shogaol analisis dengan aplikasi HEX 8.0.0. Hasil yang diperoleh dalam bentuk file pdb, data pdb divisualisaikan kemudian dianalisismenggunakan perangkat lunak Discovery Studio Client 4.1. Proses analisis meliputi energi ikatan yang terbentuk antara ligan-protein, jumlah dan jenis residu asam amino, jenis ikatan hidrogen dan adanya gaya van der waals yang terbentuk antara ligan dan protein (Bare et al., 2019).

\section{HASIL DAN PEMBAHASAN}

Ikatan antara protein JNK dan Ligan 8-shogaol membentuk interaksi (gaya van Der waals) pada 18 residu asam amino (SER193, GLY71, GLY73, ILE70, ILE124, ASP150, VAL78, VAL196, LEU148, LEU206, MET146, MET149, ALA74, ALA91, ALA151, ASN152, GLN155, dan GLU147) dan ligan 8-shogaol. Interaksi ligan dan 
protein membentuk ikatan hidrogen pada residu asam amino LYS93 berupa ikatan hydrogen convention. Ikatan yang terjadi antara 8-shogaol dan JNK membentuk energi dengan besar energi sebesar $-289.68 \mathrm{cal} / \mathrm{mol}$ (Tabel 1).

a.

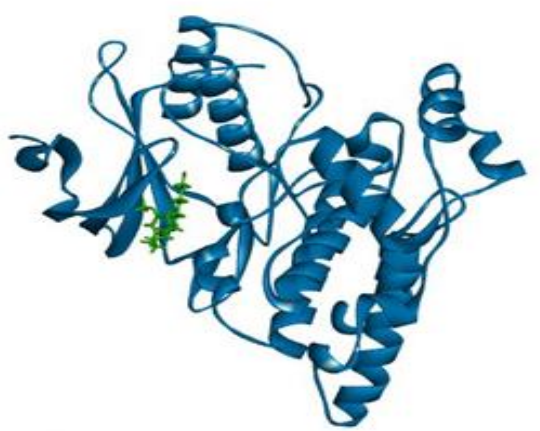

b.

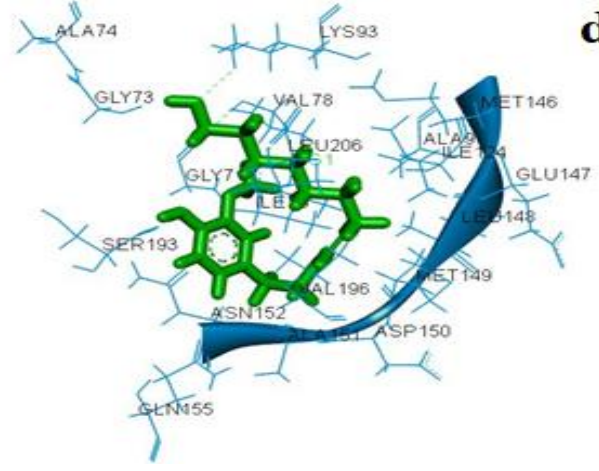

c.

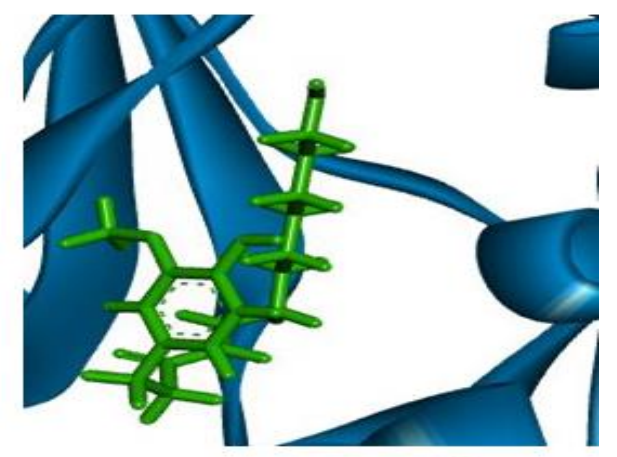

d.

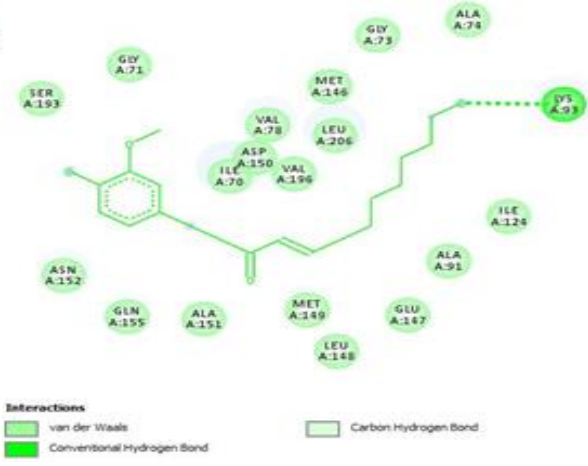

Gambar 1. Molekular interaksi antara 8-shogaol dan c-Jun N-terminal kinases (JNK). a. ikatan yang terbentuk anatara 8-shogaol- c-Jun N-terminal kinases (JNK), b. tampilan 3 Dimensi, c. Perbesaran interaksi 8-shogaol- c-Jun Nterminal kinases (JNK), d. tampilan 2 Dimensi

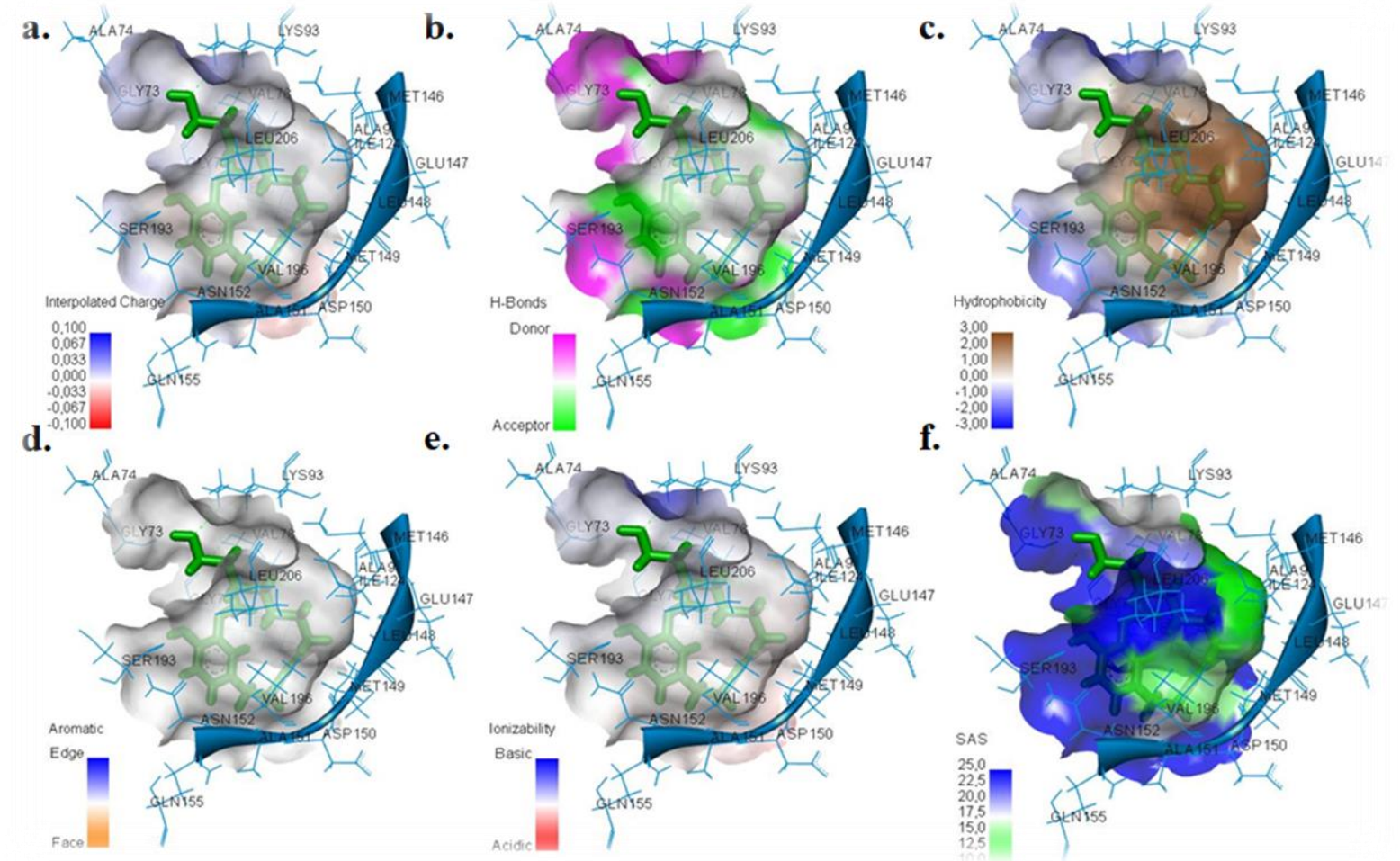

Gambar 2. Tampilan permukaan interaksi 8-shogaol dan protein c-Jun N-terminal kinases (JNK). a. Muatan permukaan ligan, b. Ikatan hydrogen liganprotein, c. Hidrofobisitas, d. Aromatic, e. Ionisasi f. Solvent accessible surface (SAS) 
Permukaan kompleks yang terbentuk antara 8-shogaol dan c-Jun N-terminal kinases (JNK) menunjukkan warna coklat yang terrlihat disebagian ebsar permukaan mengindikasikan tingkat hidrofobisitas yang tinggi (Gambar 2c). Warna ungu yang terlihat pada permukaan mengindikasikan 8-shogaol bersifat donor dan warna hijau yang terlihat pada permukaan mengartikan memiliki sifat acceptor terhadap JNK (Gambar 2b). Cincin aromatic yang terbentuk di satu tempat (Gambar 2d). Ligan memiliki muatan 0 dan bersifat netral (Gambar2e). Warna biru yang mendominasi permukaan kompleks mengindikasikan Nilai solvent accessible surface (SAS) 8-shogaol cukup tinggi (Gambar 2f). Cukup tingginya nilai SAS memiliki korelasi terhadap tingkat gaya yang terjadi van der Waals antara 8shogaol-JNK.

Tabel 1. Interaksi molekular antara ligan 8-shogaol dan protein JNK

\begin{tabular}{|c|c|c|c|c|c|c|c|}
\hline Interaksi & $\begin{array}{l}\text { Energi } \\
\text { (cal/mol) }\end{array}$ & Nama & Jarak & Kategori & $\begin{array}{l}\text { Ikatan } \\
\text { Kimia }\end{array}$ & Kimia & $\begin{array}{l}\text { Ke } \\
\text { Kimia }\end{array}$ \\
\hline \multirow{2}{*}{$\begin{array}{l}\text { 8-shogaol } \\
\text { dan c-Jun N- } \\
\text { terminal } \\
\text { kinases } \\
\text { (JNK) }\end{array}$} & \multirow{2}{*}{-289.68} & $\begin{array}{l}\text { A:LYS93:HZ2 - } \\
\text { :LIG1:O }\end{array}$ & 2.46506 & $\begin{array}{l}\text { Hydrogen } \\
\text { Bond }\end{array}$ & $\begin{array}{l}\text { Conventional } \\
\text { Hydrogen } \\
\text { Bond }\end{array}$ & $\begin{array}{c}\mathrm{H}- \\
\text { Donor }\end{array}$ & $\begin{array}{c}\text { H- } \\
\text { Acceptor }\end{array}$ \\
\hline & & $\begin{array}{l}\text { A:LYS93:HE2 - } \\
\text { :LIG1:O }\end{array}$ & 2.79954 & $\begin{array}{l}\text { Hydrogen } \\
\text { Bond }\end{array}$ & $\begin{array}{l}\text { Carbon } \\
\text { Hydrogen } \\
\text { Bond }\end{array}$ & $\begin{array}{c}\mathrm{H}- \\
\text { Donor }\end{array}$ & $\begin{array}{c}\text { H- } \\
\text { Acceptor }\end{array}$ \\
\hline
\end{tabular}

Diabetes melitus tipe 2 (DMT2) adalah penyakit metabolik dan ditandai dengan resistensi insulin dan penurunan fungsi sel beta pankreas. Kurangnya sensitifitas insulin pada diabetes memiliki korelasi terhadap fungsi kinerja JNK. Salah satu kerja JNK adalah berperan utama dalam memodulasi aksi insulin dan diabetes melitus tipe 2 (Aguirre et al., 2000). Aktivasi JNK menyebabkan disfungsi sel $\beta$ dan menganggu produksi insulin. Aksi JNK dalam sel $\beta$ pankreas serta situs perifer aksi insulin menyebabkan kerusakan sekresi insulin pada sel beta pancreas sehingga menyebabkan resistensi insulin pada DMT2 (Cui et al., 2007). JNK memiliki pengaruh terhadap sel target insulin. Kinerja JNK1/2 langsung memfosforilasi IRS1 dan IRS2 pada residu serin dan treonin. Fosfori;asi yang terjadi menyebabkan penurunan fosforilasi tirosin dari molekul IRS12 dan jalur pensinyalan PI3K-AKT sebagai respons terhadap insulin (Solinas \& Becattini, 2017).

Senyawa 8-shogaol yang terkandung dalam jahe memiliki aktivitas pada residu asam amino LYS93. Residu asam amino LYS93 berikatan dengan 8-shogaol dan membentuk ikatan hydrogen dan berpotensi untuk menutup salah sati sisi aktif JNK. Penghambatan pada salah satu sisi ini memiliki peran yang sangat penting terhadap kinerja sel-sel target insulin. Penghambatan JNK akan mengembalikan fungsi fosforilasi IRS1 dan IRS2 menjadi PI3K selanjutnya menjadi AKT. AKT yang di bentuk akan menghasilkan Insulin Metabolic Action. Dengan kembalinya fungsi dari insulin sehingga dapat mengurasi kadar gula didalam darah.

\section{KESIMPULAN}

Senyawa kimia 8-shogaol yang terkandung dalam jahe memiliki potensi sebagai terapi DMT2. Terapi ini dilakukan dengan menghambat JNK yang berperan dalam metabolisme DMT2. Interaksi ligan dan protein menunjukan ikatan hidrogen pada residu asam amini LYS93 serta van der Waals pada 18 residu asam amino. Energi 
yang terbentuk dari interaksi ligan dan protein sebesar $-289.68 \mathrm{cal} / \mathrm{mol}$. Interkasi ini berpotensi sebagai penghambat kerja JNK dan dapat digunakan dalam terapi DMT2.

\section{SARAN}

Perlu dilakukan penelitian lanjutan didalam laboratorium tentang kinerja dari 8-shogaol sebagai terapi DMT2 melalui JNK.

\section{UCAPAN TERIMAKASIH}

Ucapan terima kasih kepada pihak-pihak yang sudah membantu penulis dalam melakukan penelitian ini terutama kepada Universitas Nusa Nipa Maumere yang sudah membantu dan mendukung demi terlaksana dan selesainya penelitian ini.

\section{DAFTAR PUSTAKA}

Aguirre, V., Uchida, T., Yenush, L., Davis, R., \& White, M. F. (2000). The c-Jun NHterminal Kinase Promotes Insulin Resistance during Association with Insulin Receptor Substrate-1 and Phosphorylation of Ser. Journal of Biological Chemistry, 275(12), 9047-9054. https:// doi.org/10.1074/jbc.275.12.9047

Bare, Y., Kuki, A. D., Rophi, A. H., \& Candrakirana, G. (2019). Prediksi Asam Kuinat Sebagai Anti-Inflamasi Terhadap COX-2 Secara Virtual Virtual Prediction of Quinic Acid As Anti-Inflammation of COX-2. Biota: Jurnal Ilmiah Ilmu-Ilmu Hayati, 4, 6. https:/ / doi.org/10.24002/biota.v4i3.2516

Bare, Y., Marhendra, A., Sasase, T., \& Fatchiyah, F. (2018). Differential Expression of IL-10 Gene and Protein in Target Tissues of Rattus Norvegicus Strain Wistar Model Type 2 Diabetes Mellitus (T2DM). Acta Informatica Medica, 26(2), 87. https://doi.org/10.5455/aim.2018.26.87-92

Bare, Y., Maulidi, A., Sari, D. R. T., \& Tiring, S. S. N. D. (2019). Studi in Silico Prediksi Potensi 6-Gingerol sebagai inhibitor c-Jun N-terminal kinases (JNK). Jurnal Jejaring Matematika dan Sains, 1(2), 59-63. https://doi.org/10.36873/jjms.v1i2.211

Bare, Y., Sari, D. R. T., Rachmad, Y. T., Krisnamurti, G. C., \& Elizabeth, A. (2019). In Silico Insight the Prediction of Chlorogenic Acid in Coffee through Cyclooxygenase-2 (COX2) Interaction. Biogenesis: Jurnal Ilmiah Biologi, 7(2). https://doi.org/10.24252/bio.v7i2.9847

Bhattarai, S., Tran, V. H., \& Duke, C. C. (2001). The Stability of Gingerol and Shogaol in Aqueous Solutions. Journal of Pharmaceutical Sciences, 90(10), 1658-1664. https://doi.org/10.1002/jps.1116

Cui, J., Zhang, M., Zhang, Y., \& Xu, Z. (2007). JNK pathway: Diseases and therapeutic potential. Acta Pharmacologica Sinica, 28(5), 601-608. https:// doi.org/10.1111/j.1745-7254.2007.00579.x

Ghasemzadeh, A., Jaafar, H., Baghdadi, A., \& Tayebi-Meigooni, A. (2018). Formation of 6-, 8- and 10-Shogaol in Ginger through Application of Different Drying Methods: Altered Antioxidant and Antimicrobial Activity. Molecules, 23(7), 1646. https:// doi.org/10.3390/molecules23071646

Kesuma, D., Siswandono, S., Purwanto, B. T., \& Hardjono, S. (2018). Uji in silico Aktivitas Sitotoksik dan Toksisitas Senyawa Turunan N-(Benzoil)-N'feniltiourea Sebagai Calon Obat Antikanker. JPSCR : Journal of Pharmaceutical Science and Clinical Research, 3(1), 1. https://doi.org/10.20961/jpscr.v3i1.16266 
Solinas, G., \& Becattini, B. (2017). JNK at the crossroad of obesity, insulin resistance, and cell stress response. Molecular Metabolism, 6(2), 174-184. https://doi.org/10.1016/j.molmet.2016.12.001

Tiring, S. S. N. D., Bare, Y., Maulidi, A., Nugraha, F. A. D., \& S, M. (2019). Studi In Silico: Prediksi Potensi 6-Shogaol dalam ZIngiber officinale sebagai Inhibitor JNK. Al Kimia, 07(02). https://doi.org/10.24252/al-kimia.v7i2.10638 